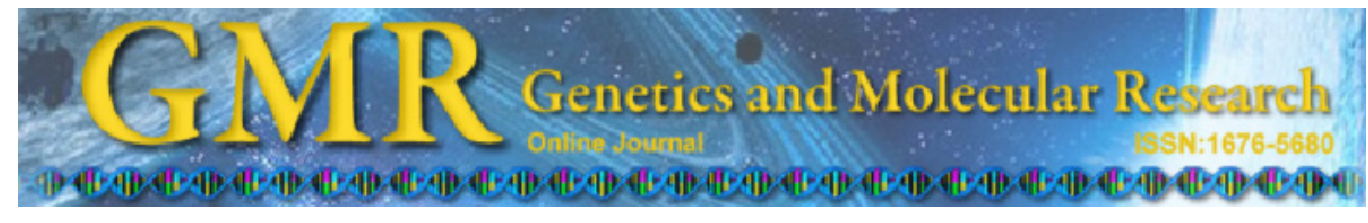

\title{
Polymorphism in Metarhizium anisopliae var. anisopliae (Hypocreales: Clavicipitaceae) based on internal transcribed spacer-RFLP, ISSR and intron markers
}

P.V. Tiago ${ }^{1}$, M.P. Carneiro-Leão ${ }^{1}$, M.L.A. Lima ${ }^{2}$, N.T. Oliveira ${ }^{1}$ and E.A. Luna-Alves Lima ${ }^{1}$

ABSTRACT. anisopliae

anisopliae

\section{Mahanarva fimbriolata}

anisopliae

anisopliae

\section{Metarhizium}

anisopliae

$M$ 


\section{INTRODUCTION}

\section{Metarhizium anisopliae}

used in fighting a number of pests, particularly the sugar cane root spittlebug, Mahanarva fimbriolata

intraspecific variations of Metarhizium Beauveria

\section{Metarhizium}

technique, given the polymorphism observed, was used in designing specific primers for $M$. anisopliae anisopliae M. anisopliae acridum

veria bassiana

M. anisopliae

Beau-

(random amplified polymorphic DNA), SSR (simple sequence repeats) and AFLP (ampli fied fragment length polymorphism) have also been deployed in genetic variability studies of M. anisopliae

pliae

M. anisopliae aniso-

formative system for the DNA fingerprinting of these isolates and helping their detection in laboratory and field work.

MATERIAL AND METHODS

Isolates of Metarhizium anisopliae var. anisopliae and DNA extraction

M. anisopliae anisopliae

M. fimbriolata 
fimbriolata

acridum

M. anisopliae

um filtration and washed using sterile distilled water. The wet weight was determined for extrac

\section{Amplification of the ITS region of rDNA}

Amplification reactions were performed in a final volume of $25 \mu \mathrm{L}$ containing reaction

Carlsbad, CA, USA), primers ITS4 and ITS5, $0.2 \mu \mathrm{M}$ each (Bioneer, Daedeok-gu, Daejeon, South Korea), $0.04 \mathrm{U} / \mu \mathrm{L}$ Taq DNA polymerase (Invitrogen) and $25 \mathrm{ng}$ DNA, and the reactions were based on a modification of the method of Lima (2005). Amplification was according to

$55^{\circ} \mathrm{C}$ for $1 \mathrm{~min}$, and $72^{\circ} \mathrm{C}$ for $2 \mathrm{~min}(40$ cycles $)$, and a final extension at $72^{\circ} \mathrm{C}$ for 5 min $(1$ cycle). The amplification products of the locus ITS1-5.8S-ITS2 of rDNA were separated by

\section{ITS-RFLP - locus ITS1-5.8S-ITS2 of rDNA}

The enzymatic digestion was carried out by mixing $4 \mu \mathrm{L}$ PCR product from the ITS regions of rDNA with $16 \mu \mathrm{L}$ restriction mix containing $0.1 \mathrm{U}$ of the restriction enzymes: Dra Pst Msp Eco Hae Hin Bsh in specific restriction buffer. Each reaction was incubated at $37^{\circ} \mathrm{C}$ for $3 \mathrm{~h}$. The fragments ob

\section{ISSR}

The amplification reactions were performed in a final volume of $25 \mu \mathrm{L}$ containing reac

$0.25 \mu \mathrm{M}$ primers GACA (Bioneer), $0.04 \mathrm{U} / \mu \mathrm{L}$ Taq DNA polymerase (Invitrogen), and 25 ng DNA, and the reactions were based on a modification of the method of Lima (2005). Ampli fication was according to the following program: an initial denaturation at $93^{\circ} \mathrm{C}$ for $5 \mathrm{~min}(1$ cycle); $93^{\circ} \mathrm{C}$ for $20 \mathrm{~s}, 55^{\circ} \mathrm{C}$ for $45 \mathrm{~s}$, and $72^{\circ} \mathrm{C}$ for 1 min $30 \mathrm{~s} \mathrm{(40} \mathrm{cycles),} \mathrm{and} \mathrm{a} \mathrm{final} \mathrm{exten}$ sion at $72^{\circ} \mathrm{C}$ for $6 \mathrm{~min}(1 \mathrm{cycle})$. For the primer M13, the reactions were carried out in a final volume of $25 \mu \mathrm{L}$ containing reaction buffer $(20 \mathrm{mM}$ Tris- $\mathrm{HCl}, \mathrm{pH} 8.4,50 \mathrm{mM} \mathrm{KCl}), 2.0 \mathrm{mM}$

, $0.25 \mathrm{mM}$ dNTP (Invitrogen), $0.5 \mu \mathrm{M}$ primer M13 (Bioneer), $0.04 \mathrm{U} / \mu \mathrm{L}$ Taq DNA polymerase (Invitrogen) and $25 \mathrm{ng}$ DNA, and reactions were based on a modification of the 
a final extension at $72^{\circ} \mathrm{C}$ for $5 \mathrm{~min}(1 \mathrm{cycle})$. The amplification products were separated by

\section{Intron splice site primer}

Amplification reactions were performed in a final volume of $25 \mu \mathrm{L}$ containing re

(Invitrogen), $0.5 \mathrm{mM}$ primer EI1 (Bioneer), $0.04 \mathrm{U} / \mu \mathrm{L}$ Taq DNA polymerase (Invitrogen) and $25 \mathrm{ng}$ DNA, and reactions were based on a modification of the method of Lima (2005). Amplification was carried out using the following program: an initial denaturation at $94^{\circ} \mathrm{C}$ a final extension at $74^{\circ} \mathrm{C}$ for $5 \min (1$ cycle). Amplification products were separated using

\section{Analysis of the molecular data}

using Jaccard's coefficient. After similarity was determined, a dendrogram was generated us

. The Arlequin 3.11 program (Excoffier et al.,

\section{RESULTS}

The product of the amplification of locus ITS1-5.8S-ITS2 of rDNA, using primers

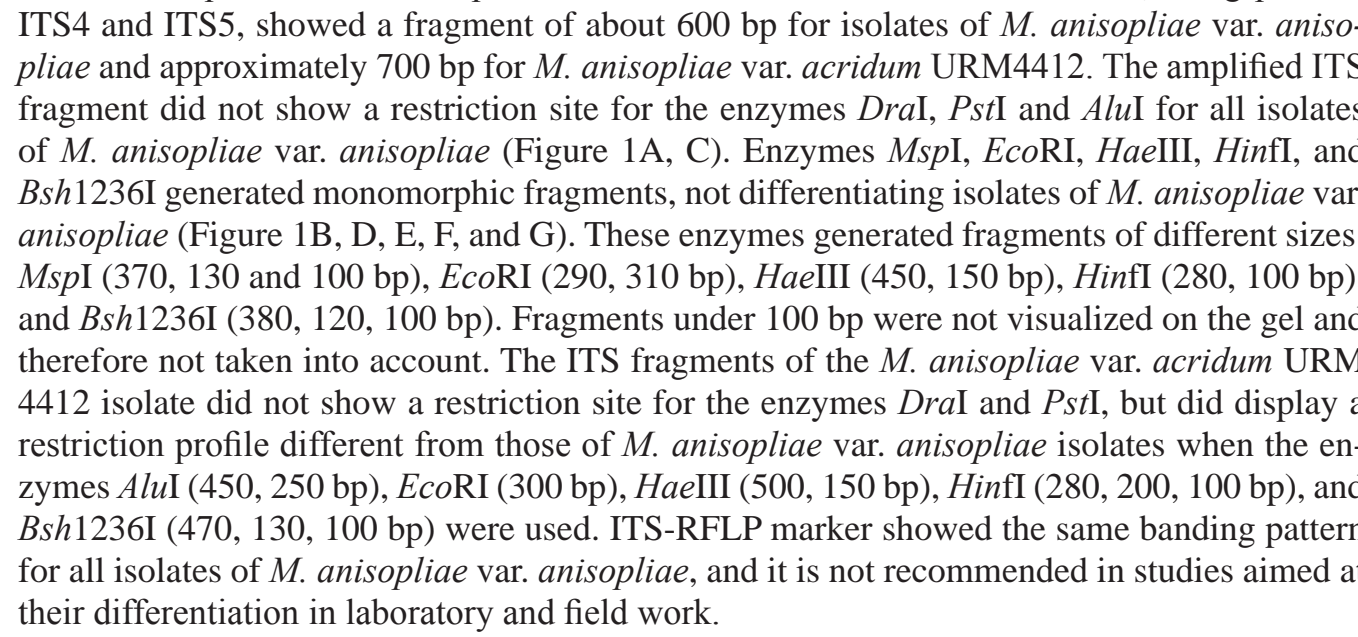




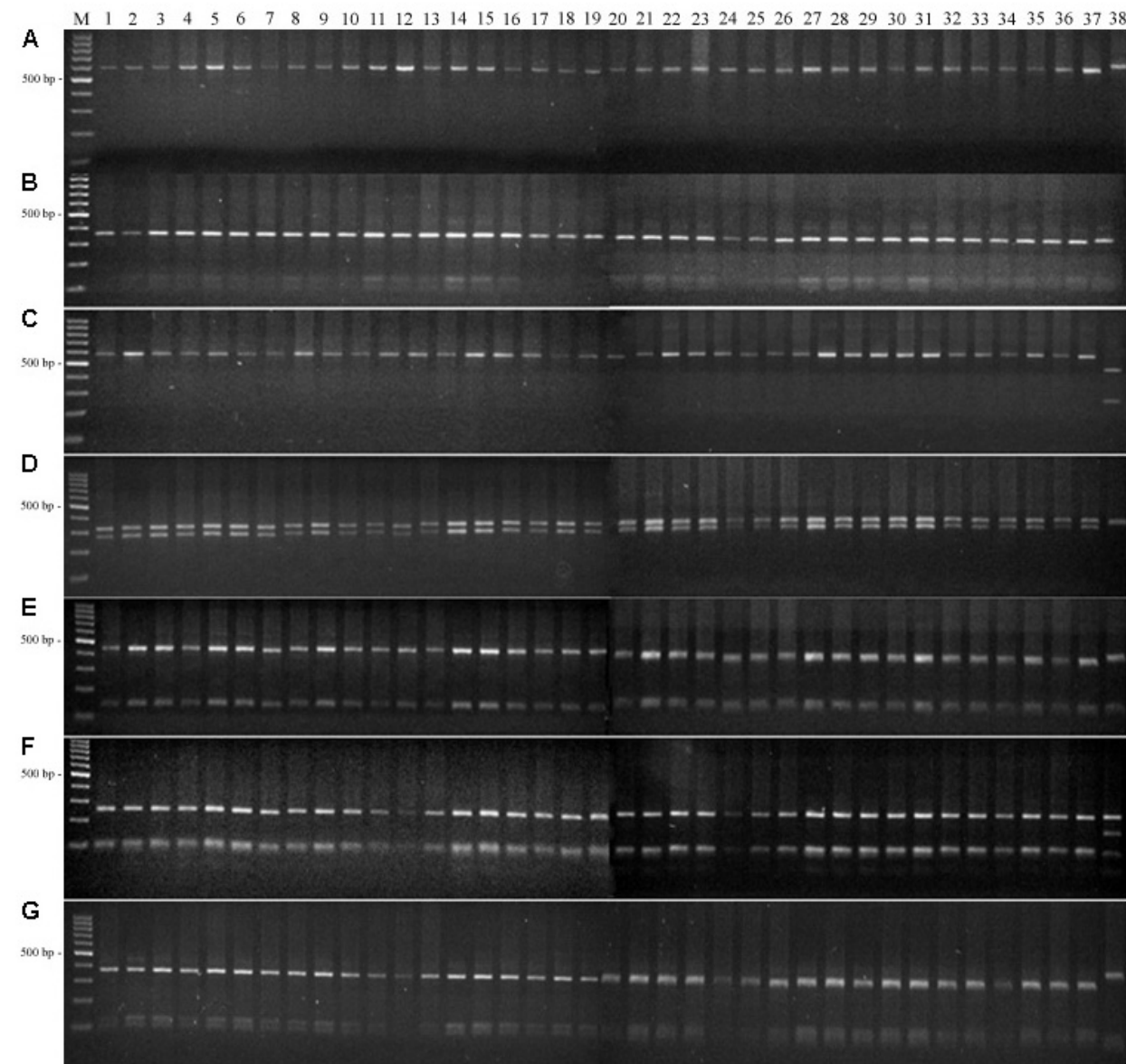

Figure 1. DNA fragment restriction profiles of the ITS region of rDNA obtained with the enzymes: A. Dra Pst

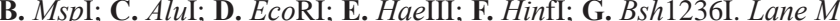
$137 \quad$ Metarhizium anisopliae anisopliae Lane 38 M. anisopliae acridum

band profiles, using two of the four primers tested, with the last two having been obtained M. anisopliae anisopliae 

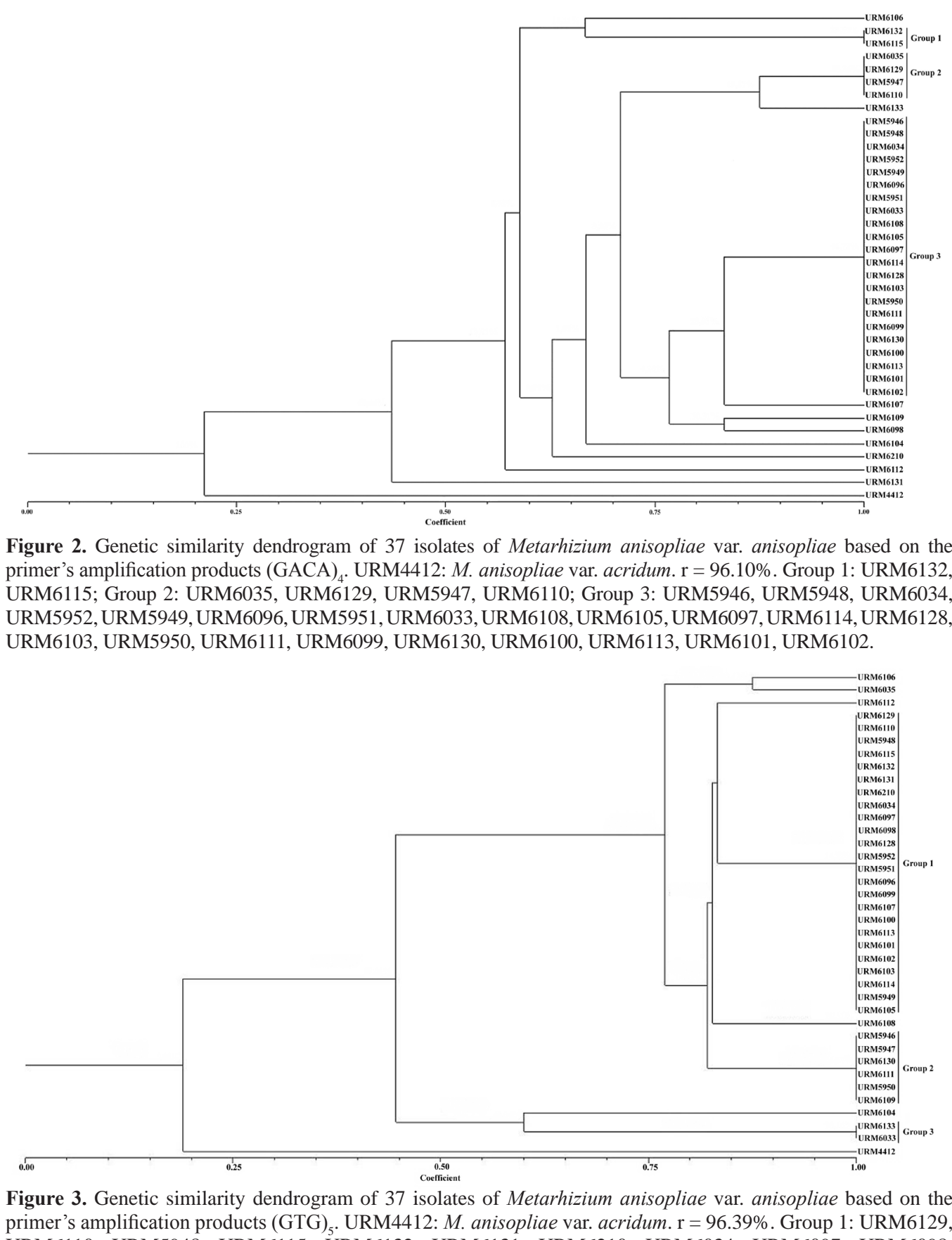

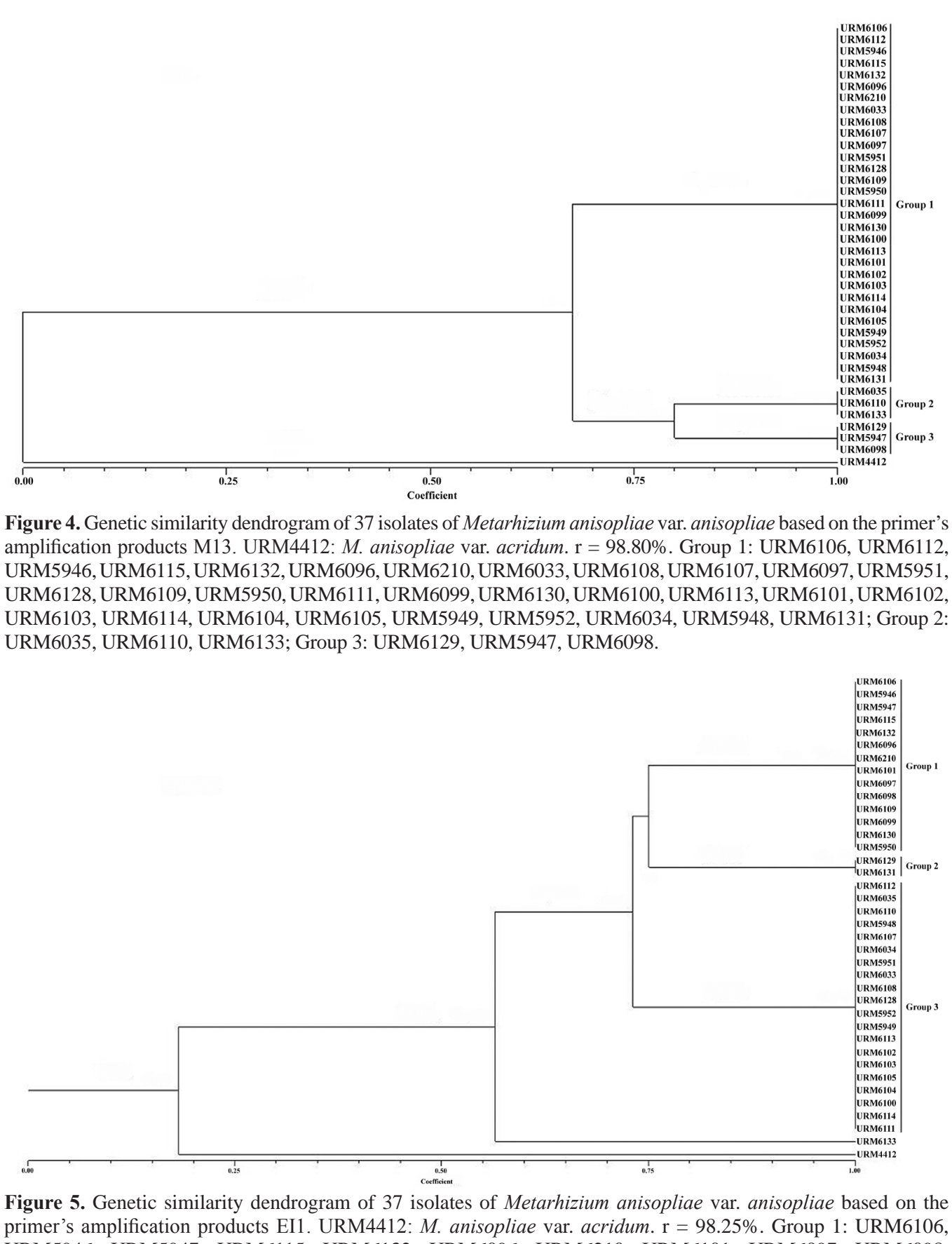
M. anisopliae anisopliae
pliae acridum
$89.80 \%$ and that variability within them was 10.19 to $22.89 \%$. Fifteen exclusive amplifica

\begin{tabular}{llll} 
anisopliae anisopliae & M. anisopliae acridum & M. \\
$\begin{array}{l}\text { Table } \mathbf{1 .} \\
\text { anisopliae . anisopliae }\end{array}$ & M. anisopliae & . acridum & Metarhizium \\
\hline
\end{tabular}

c.

\section{DISCUSSION}

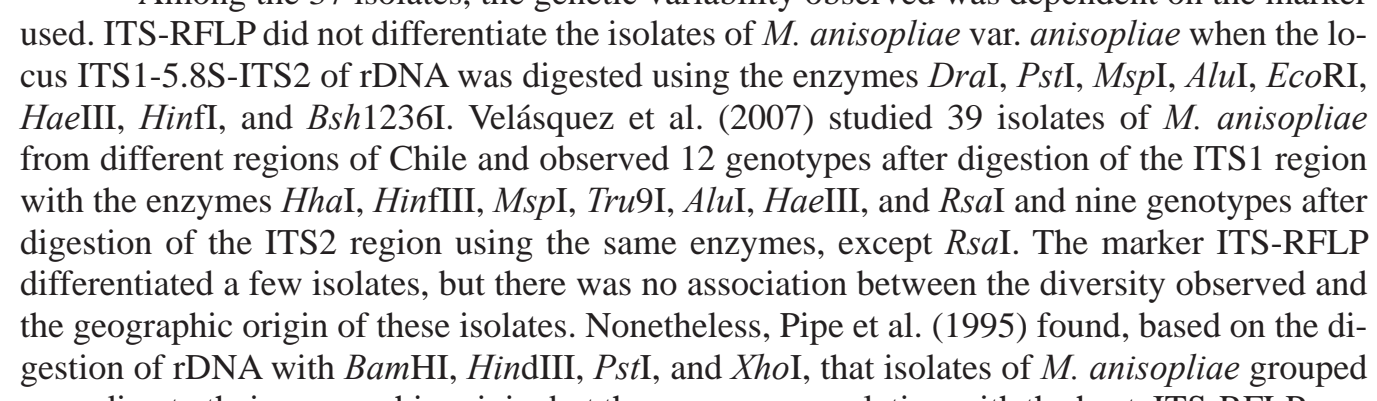

also used in intraspecific differentiation studies of $B$. bassiana

B. brongniartii 
Entomophthora muscae

muscae

\section{Hae ,Hpa Eco Pst Alu Mbo B. brongniartii}

B. bassiana

E.

and M13 and intron EI1 primers were used in studying polymorphism in fifteen M. anisopliae anisopliae M. anisopliae acridum

detecting the intraspecific variability among different $M$. anisopliae

M. anisopliae anisopliae M. posticata

M. anisopliae

B. bassiana

E. muscae

Pandora neoaphidis

bassiana

$B$.

M. anisopliae

B. brongniartii

B. bassiana

M. anisopliae M. fimbriolata

M. fimbriolata 


\section{M. anisopliae}

provide DNA fingerprinting for some isolates. These markers can be successfully used in stud ies targeting their detection in laboratory and field work, enabling the monitoring of isolates after their application in the field.

\section{ACKNOWLEDGMENTS}

grant given to P.V. Tiago) and the National Council for Technical and Scientific Development (Conselho Nacional de Desenvolvimento Científico e Tecnológico - CNPq).

\section{REFERENCES}

Beauveria bassiana

The use of amplified fragment length polymorphism for molecular

FEMS Microbiol. Lett.

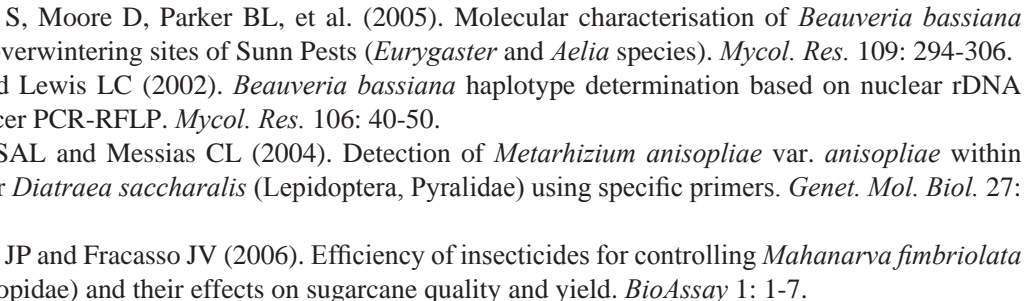

$$
\text { BioAssay }
$$

Entz SC, Johnson DL and Kawchuk LM (2005). Development of a PCR-based diagnostic assay for the specific detection Metarhizium anisopliae acridum Mycol. Res.

Cell Mol. Biol. Lett.

Beauveria bassiana

Excoffier L, Laval G and Schneider S (2005). Arlequin (version 3.0): an integrated software package for population Evol. Bioinform. Online

anisopliae

$$
\text { Hypothenemus hampei }
$$

\section{J. Invertebr. Pathol.}

World J. Microbiol. Biotechnol.

Beauveria bassiana

Metarhizium anisopliae anisopliae

Jensen AB, Thomsen L and Eilenberg J (2001). Intraspecific variation and host specificity of Entomophthora muscae sensu stricto isolates revealed by random amplified polymorphic DNA, universal primed PCR, PCR-restriction J. Invertebr. Pathol.

gloeosporioides Fusarium oxysporum Rev. UNIMAR

Colletotrichum

Fungal Ecol.

Metarhizium

Entomophthora muscae 
Metarhizium anisopliae B.M.C. Microbiol. Mavridou A, Cannone J and Typas MA (2000). Identification of group-I introns at three different positions within the 28S Metarhizium anisopliae anisopliae Fungal Genet. Biol.

Beauveria brongniartii

brongniartii Mol. Ecol.

fimbriolata
Mycol. Res.

Global Sci. Technol.

Metarhizium anisopliae Mycol. Res.

Aspergillus nidulans Adv. Genet.

Beauveria

Mahanarva

Beauveria

Beauveria bassiana

anchored polymerase chain reaction (ISSR-PCR) amplification. Appl. Entomol. Zool.

Pandora neoaphidis Mycol. Res.

Genet. Mol. Biol.

Metarhizium anisopliae

(2007). Intraspecific differentiation of Chilean isolates of anisopliae 